\title{
Expression, function, and regulation of the testis-enriched heat shock $H S P A 2$ gene in rodents and humans
}

\author{
Dorota Scieglinska $\cdot$ Zdzislaw Krawczyk
}

Received: 14 July 2014 / Revised: 3 October 2014 / Accepted: 9 October 2014 /Published online: 25 October 2014

(C) The Author(s) 2014. This article is published with open access at Springerlink.com

\begin{abstract}
The $H S P A 2$ gene is a poorly characterized member of the HSPA (HSP70) family. HSPA2 was originally described as testis-specific and expressed at the highest level in pachytene spermatocytes of rodents, the expression of which is not induced by heat shock. HSPA2 is crucial for male fertility. However, recent advances have shown that HSPA2 is expressed in various tumors and in certain types of somatic tissues. In this review, we summarize the current knowledge on the HSPA2 expression pattern, including information on transcriptional, translational, posttranslational, and epigenetic mechanisms which regulate HSPA2 expression. We also present and discuss the current views concerning the functions of the HSPA2 protein in spermatogenetic, somatic, and cancer cells. The knowledge of the properties of HSPA2, although limited, shows this protein as a unique member of the HSPA family. However, understanding whether this protein could become a relevant cancer biomarker or a therapeutically applicable target requires extensive further studies.
\end{abstract}

Keywords Heat shock genes · HSPA2 - Spermatogenic cells · Somatic cells $\cdot$ Cancer $\cdot$ Cytoprotection $\cdot$ Regulation of expression

\section{Introduction}

More than 50 years ago, studies of Ferrucio Ritossa (Ritossa 1962) paved the way for exciting research which resulted in the discovery of a cellular reaction known as the heat shock

D. Scieglinska $(\square) \cdot$ Z. Krawczyk

Maria Skłodowska-Curie Memorial Cancer Center and Institute of Oncology, Gliwice Branch, Wybrzeże Armii Krajowej 15,

44-101 Gliwice, Poland

e-mail: dorotas@io.gliwice.pl response. As we know now, this is a highly universal response of almost all kinds of cells and all species exposed to factors/ conditions that could affect the normal structure of cellular proteins. The major feature of the heat shock response is the rapid induction or considerable stimulation of the expression of genes encoding heat shock proteins (HSPs), the function of which is to minimize the harmful effects of environmental or endogenous molecular stressors (Gidalevitz et al. 2011). As a result of long-term studies, multiple HSPs and HSP-related proteins have been identified which are classified (mostly on the basis of similar molecular weights and amino acid sequence similarity) into several families. Guidelines for the nomenclature of the human HSPs have been recommended by Kampinga et al. (2009), and in this review, we will follow them.

The general function of HSPs, regarded as molecular chaperones, is their involvement in the maintenance of intracellular homeostasis, primarily by controlling the process of protein folding. Many HSPs act as molecular partners for other highly specialized proteins such as signal transducers and transcription factors. HSPs also exhibit anti-apoptotic properties and, as well, can modulate various immune responses. All these properties make HSPs of prime interest in various fields of medicine as potential clinically useful markers or targets for therapeutic intervention (Kakkar et al. 2014; Ciocca et al. 2013).

The largest group of heat shock proteins is the HSPA (HSP70) family (Table 1), which in humans contains at least 13 members, only some of which are highly heat/stress inducible (Kampinga et al. 2009). Within the HSPA family, there are two genes, namely HSPA2 and HSPA1L, which were originally identified as highly specific for spermatogenesis. The aim of this review is to summarize the current knowledge on HSPA2 gene expression and regulation as well as to discuss possible functions of the gene in spermatogenic, normal somatic, and cancer cells. 
Table 1 Genes belonging to the HSPA family in human genome

\begin{tabular}{|c|c|c|c|c|c|}
\hline Name & Other names & Locus & $\begin{array}{l}\text { Entrez } \\
\text { gene ID }\end{array}$ & $\begin{array}{l}\text { Protein size (molecular } \\
\text { mass kDa) }\end{array}$ & $\begin{array}{l}\text { Protein homology } \\
(\%)^{\mathrm{a}}\end{array}$ \\
\hline HSPA1A & HSP70-1; HSP72; HSPA1 & $6 \mathrm{p} 21.33$ & 3303 & $641(70,0)$ & 83.5 \\
\hline HSPA1B & HSP70-2 ${ }^{\mathrm{b}}$ & $6 \mathrm{p} 21.32$ & 3304 & $641(70,0)$ & 83.5 \\
\hline HSPA1L & hum70t; hum70t; Hsp-hom & $6 \mathrm{p} 21.33$ & 3305 & $641(70,4)$ & 82 \\
\hline HSPA2 & Hsp70-2 ${ }^{\mathrm{b}}, \mathrm{Hsp} 70.2$ & $14 \mathrm{q} 23.3$ & 3306 & $639(70,0)$ & 100 \\
\hline HSPA5 & BIP; GRP78; MIF2 & $9 \mathrm{q} 33.3$ & 3309 & $654(71,0)$ & 60.9 \\
\hline HSPA6 & Heat shock $70 \mathrm{kD}$ protein $6\left(\mathrm{HSP} 70 \mathrm{~B}^{\prime}\right)$ & $1 \mathrm{q} 23.3$ & 3310 & $643(71,0)$ & 78.3 \\
\hline HSPA7 & & $1 \mathrm{q} 23.3$ & 3311 & ND & ND \\
\hline HSPA & HSC70; HSC71; HSP71; HSP73 & $11 \mathrm{q} 24.1$ & 3312 & $646(70,9)$ & 86.3 \\
\hline HSPA9 & GRP75; HSPA9B; MOT; MOT2; PBP74 & $5 \mathrm{q} 31.2$ & 3313 & $679(73,7)$ & 46 \\
\hline HSPA12A & FLJ13874; KIAA0417 & $10 \mathrm{q} 25.3$ & 259217 & $675(141,0)$ & 13.1 \\
\hline$H S P A 12 B$ & RP23-32L15.1; 2700081N06Rik & $20 \mathrm{p} 13$ & 116835 & $686(75,7)$ & 14.5 \\
\hline HSPA13 & Stch & $21 \mathrm{q} 11.2$ & 6782 & $471(51.9)$ & 23.8 \\
\hline HSPA14 & HSP70-4; HSP70L1; MGC131990 & $10 \mathrm{p} 13$ & 51182 & $509(54,8)$ & 28.3 \\
\hline
\end{tabular}

$N D$ no data

${ }^{\text {a } A m i n o ~ a c i d ~ h o m o l o g y ~ t o ~ t h e ~ p r o t e i n ~ e n c o d e d ~ b y ~ H S P A 2 ~}$

${ }^{\mathrm{b}}$ Please note that in the literature, the same name was sometimes used for two different genes, e.g., HSPA1B and HSPA2

\section{Cloning and structure of the HSPA2 gene}

The first clue suggesting the existence of a testis-specific hsp70-related gene was the detection in total RNA isolated from rat testis of a highly abundant $2.7-\mathrm{kb}$ transcript which hybridized with DNA probes derived from Drosophila or human heat-inducible hsp 70 genes and with mouse genomic DNA sequences (then unidentified) cloned into the pM1.8 plasmid (kindly given to us by Dr. Rick Morimoto) (Krawczyk et al. 1987b). The expression pattern of the 2.7$\mathrm{kb}$ transcript during the seminiferous epithelium cycle and postnatal testis development, and the disappearance of this transcript from testis of rats exposed to factors which impaired spermatogenesis with concomitant degeneration of seminiferous epithelium, indicated the corresponding gene to be highly and selectively activated in pachytene spermatocytes (Krawczyk et al. 1987a; Krawczyk et al. 1988; Krawczyk and Szymik 1989). The gene was isolated from a rat genomic library, cloned, and named Hst70 (Wisniewski et al. 1990). The current name is HSPA2 (Entrez Gene ID: 60460).

In a parallel study, Zakeri and Wolgemuth (1987) found in the testis of adult mice a similar $2.7-\mathrm{kb}$ transcript, which hybridized with a DNA probe corresponding to the murine heat-inducible $h s p 70 / h s p 68$ gene. This transcript was abundantly expressed in postmeiotic early spermatids but was barely detectable in prophase spermatocytes. Such an expression pattern suggested that this particular transcript was coded rather by a spermatid-specific gene. This gene was characterized later and named Hsc70t (current name; HSPA1L, Entrez Gene ID: 15482) by Matsumoto and Fujimoto (1990).
The mouse counterpart of the rat hst70/HSPA2 gene was identified by Zakeri et al. (1988) by screening a mouse DNA genomic library with the above-mentioned pM1.8 plasmid as a probe. Cloning and sequencing of the murine ortholog of the rat hst70/HSPA2 gene (then named Hsp70-2; Entrez Gene ID: 15512) confirmed that its $5^{\prime}$ end fragment was present in the pM1.8 genomic DNA clone (Zakeri et al. 1988).

The structure of the transcription unit of the rat and mouse HSPA2 gene is similar. They have an intron within the $5^{\prime}$ untranslated region and two main transcription start sites (T2 and T1) located at around 116 base pairs (bp) and around 351bp upstream of the ATG codon (numbers related to the position in the rat gene) respectively (Widłak et al. 1994, 1995; Dix et al. 1996b; Scieglinska et al. 2001). Accordingly, two variants of the HSPA2 transcripts are synthesized in mouse and rat testis, both having a similar size $(2.7 \mathrm{~kb})$ but a different structure of their $5^{\prime}$ end. The population which originates from the distant T1 transcription start site undergoes splicing. The second, non-spliced variant of messenger RNA (mRNA) originates from the T2 start site (approx. 116-bp upstream of ATG) placed within the intron (Scieglinska et al. 2001).

The human HSPA2 gene (Gene Entrez ID: 3306), which has been cloned from a human placenta genomic library (Bonnycastle et al. 1994), encodes a protein with 98.2 and $98.4 \%$ amino acids (aa) sequence similarity to its mouse and rat counterparts, respectively. The most conspicuous difference between the human and rodent HSPA2 protein is the insertion of 7 aa near the carboxyl end (aa 623-629) of human HSPA2. Transcription of the human HSPA2 gene initiates at a single transcription start site, which corresponds to the T2 site of the rodent ortholog gene (placed 109-bp upstream of the 
ATG codon) (Piglowski et al. 2007). The human gene, localized at 14q24.3 (Bonnycastle et al. 1994), has no intron(s) and its expression gives rise to only one population of mRNA molecules (Piglowski et al. 2007).

The human and rodent HSPA2 genes show the highest amino acid sequence similarity ( $86.3 \%$ ) to the HSPA8 gene. According to a recent study, in which phylogenetic trees of the human HSPA genes have been computed based on the alignment of their protein products, HSPA2 together with HSPA8 groups into one of three subgroups of one of the seven major evolutionary-related groups of $H S P A$ genes. A second subgroup of this group includes HSPA1A, HSPA1B, and HSPA1L genes while the third one includes HSPA6 and HSPA7 genes (Brocchieri et al. 2008). Evolutionary analysis presented by Brocchieri et al. 2008 also suggested that the sequence of HSPA2, HSPA1, and HSPA6 genes originated from the HSPA8 gene by retrotransposition.

\section{Expression pattern of the HSPA2 gene in normal somatic and pathological tissues}

Although initially the HSPA2 gene was described as testisspecific, subsequent studies revealed that it could be expressed also in somatic tissues. The first hint which pointed to this came from the study of transgenic (TG) mice, because a transgene composed of a chloramphenicol acetyltransferase (CAT) reporter gene fused to the rat HSPA2 promoter was expressed not only in the testis, but also in the brain (Widłak et al. 1995). The expression of the HSPA2 gene in the mouse brain, at the highest level in the hippocampus, was subsequently shown by Northern blotting and in situ hybridization (Murashov and Wolgemuth 1996b). The use of the more sensitive RT-PCR method enabled detection of low levels of HSPA2 mRNA present in multiple rat and mouse tissues, except liver (Scieglińska et al. 1997; Dix et al. 1996b). Activity of the HSPA2 promoter was also observed during mouse embryogenesis (Murashov and Wolgemuth 1996a; Rupik et al. 2006).

A study aimed to identify cell types which express the HSPA2 gene was performed in TG mice bearing the transgene composed of the rat HSPA2 promoter and an enhanced green fluorescent protein $(E G F P)$ reporter. Visualization of EGFP fluorescence in TG mice tissues and detection of endogenous HSPA2 protein (by Western blot and immunohistochemistry) indicated that HSPA2 expression is restricted to certain types of tissues and specific cells (Vydra et al. 2009; Table 2).

The finding of abundant anti-sense transcript $(2.8 \mathrm{~kb})$ in somatic mouse tissues, detected mainly in various brain structures (Murashov and Wolgemuth 1996a, b), suggests a high complexity of the HSPA2 expression pattern in rodents.
However, at present, a functional meaning of this anti-sense RNA is entirely obscure.

The first study on the expression of HSPA2 mRNA in human tissues showed an abundant HSPA2 transcript in a majority of somatic tissues with the exception of liver and peripheral blood leukocytes (Bonnycastle et al. 1994; Table 2). Subsequent studies confirmed the expression of HSPA 2 mRNA in numerous immortalized non-tumorigenic cell lines derived from breast, bronchus, and prostate (Rohde et al. 2005; Piglowski et al. 2007; Scieglińska et al. 2008), although not in cell lines derived from human embryonic kidney (Hageman et al. 2011) and normal urothelium (Garg et al. 2010b). The search for HSPA2 protein performed by immunohistochemistry using multitissue microarrays and a highly specific anti-HSPA2 anti-serum revealed that beside testicular cells, HSPA2 is expressed in several tissues in a cell-type-specific manner (Scieglinska et al. 2011; Table 2).

The bioinformatic data available in the BioGPS (www. biogps.org) and UNIGENE (www.ncbi.nlm.nih.gov/ unigene) databases support the view that the HSPA2 gene can be expressed in multiple, but not all, somatic tissues. UNIGENE predicts approximate expression patterns by assessing the relative number of expressed sequence tags (ESTs) per tissue, while BioGPS collects data obtained through analysis of high-density oligonucleotide arrays. According to these databases, the highest level of HSPA2 transcripts can be found in the testis and brain of both human and mouse. In other tissues, the mRNA is present at substantially lower levels, if any (Table 2). However, the pattern of HSPA2 gene transcription in human and mouse somatic tissues is not fully overlapping, and the relative abundance of the HSPA 2 mRNA is significantly higher in human than in mouse somatic tissues (Table 2).

The expression of the HSPA2 gene, both at protein and mRNA levels, was also demonstrated by several groups in cancer cell lines originated from various human malignancies as well as in primary malignant tumors (details in Table 3). Our recent immunohistochemical study with the use of tissue microarrays demonstrated that the HSPA2 protein is widely expressed in human malignancies, although the percentage of HSPA2-positive samples may vary between different tumor histotypes (Scieglinska et al. 2014). For instance, HSPA2 was found in a majority of skin, breast, or lung squamous cell cancer (SCC) cases, but only in a minority of prostate and lung adenocarcinomas (Scieglińska et al. 2008, 2014). Because high HSPA2 expression was associated with negative prognosis in esophageal SCC, non-small cell lung cancer (NSCLC), and liver hepatocellular cancer (HCC) patients (Zhang et al. 2013; Scieglinska et al. 2014; Fu et al. 2014), it seems that this protein could be a clinically relevant cancer biomarker (Table 3). We discuss the possible influence of HSPA2 on cancer phenotype in the later section of this review 
Table 2 Summary on the expression of the HSPA2 gene in selected human and mouse tissues

\begin{tabular}{|c|c|c|c|c|c|c|c|c|c|}
\hline & \multicolumn{5}{|c|}{ Human HSPA2; Gene ID: 3306} & \multicolumn{4}{|c|}{ Mouse HSPA2 (Hsp70.2); Gene ID: 15512} \\
\hline & $\begin{array}{l}\text { Northern } \\
\text { blot }^{\mathrm{a}}\end{array}$ & BioGPS $^{b}$ & $\mathrm{EST}^{\mathrm{c}}$ & Protein $^{\mathrm{d}}$ & Cell type $^{\mathrm{d}}$ & BioGPS $^{e}$ & $\mathrm{EST}^{\mathrm{c}}$ & Protein $^{f}$ & Cell type ${ }^{f}$ \\
\hline Adrenals & nd & 19.6 & 60 & + & $\begin{array}{l}\text { Cortex-zona reticularis } \\
\text { cells }\end{array}$ & 43.8 & 0 & + & Medulla_chromaffin cells \\
\hline Bladder & nd & nd & 0 & - & - & 190.5 & 61 & + & $\begin{array}{l}\text { Muscularis; urothelium-umbrella } \\
\text { cells }\end{array}$ \\
\hline Lung & + & 230.9 & 17 & + & Bronchial epithelium & 57.5 & 30 & + & Bronchial epithelium \\
\hline Heart & + & 34.4 & 67 & - & - & 20.7 & 0 & - & - \\
\hline Brain & ++ & 2189.0 & 641 & + & $\begin{array}{l}\text { Glial cells, ependymal } \\
\text { cells }\end{array}$ & 145.4 & 73 & + & $\begin{array}{l}\text { Cortex_pyramidal cells; cerebellum } \\
\text { —Purkinje cells; dentate gyrus- } \\
\text { granular and molecular layers; } \\
\text { hippocampus - mossy fiber; } \\
\text { ependyma; pia mater, choroid } \\
\text { plexus, subcommissural organ; } \\
\text { neurons in subventricular zone }\end{array}$ \\
\hline Colon & ++ & 369.1 & 76 & + & $\begin{array}{l}\text { Epithelium_-goblet cells; } \\
\text { smooth muscle fibers } \\
\text { of lamina muscularis } \\
\text { mucosae }\end{array}$ & 18.8 & nd & nd & nd \\
\hline Kidney & ++ & 252.4 & 198 & + & Cortex-distal tubules & 18.4 & 0 & & Parietal layer of Bowman's capsules \\
\hline Liver & - & 33.6 & 4 & - & - & 18.0 & 0 & - & - \\
\hline Ovary & ++ & 9.9 & 9.0 & nd & nd & 89.5 & 0 & + & $\begin{array}{l}\text { Oocytes from primodial and primary } \\
\text { follicles, follicle - granulosa cells, } \\
\text { ovarian mesothelium }\end{array}$ \\
\hline Placenta & ++ & 229.0 & 687.6 & nd & nd & 32.9 & nd & nd & nd \\
\hline Prostate & + & 51.2 & 21 & - & - & 52.6 & 0 & + & Cuboidal epithelial cells \\
\hline Skeletal muscle & +++ & 29.8 & 27 & - & - & 25.0 & 36 & nd & nd \\
\hline Skin & nd & 19.2 & 147 & + & Epidermis_-basal layer & nd & 58 & + & Hair bulbs, epidermis \\
\hline Small intestine & ++ & 185.7 & nd & + & $\begin{array}{l}\text { Epithelium_-goblet cells, } \\
\text { paneth cells; smooth } \\
\text { muscle fibers of lamina } \\
\text { muscularis mucosae }\end{array}$ & 38.6 & nd & + & $\begin{array}{l}\text { Epithelium-goblet cells; muscularis, } \\
\text { enteric ganglia }\end{array}$ \\
\hline Spleen & + & nd & 92 & - & - & 13.1 & 10 & + & Peyer's patches \\
\hline Testis & +++ & 2276.0 & 553 & + & $\begin{array}{l}\text { Spermatocytes and } \\
\text { spermatids }\end{array}$ & 6748.9 & 344 & + & Spermatocytes and spermatids \\
\hline Thyroid & nd & 44.6 & 0 & - & - & nd & 0 & nd & nd \\
\hline
\end{tabular}

${ }^{\text {a }}$ Results according to Bonnycastle et al. (1994); nd no data, + weak, ++ moderate, +++ strong hybridization signal

${ }^{\mathrm{b}}$ Data on expression of human HSPA2 extracted from BioGPS database; expression values obtained for 211538 s_at probe set; $n d$ no data

${ }^{\mathrm{c}}$ Number of ESTs corresponding to the HSPA2 gene per million transcripts in the given tissue; data on relative EST number extracted from the UNIGENE database (www.ncbi.nlm.nih.gov/unigene); nd no data

${ }^{\mathrm{d}}$ Results of protein expression in human tissues according to Scieglinska et al. (2011); $n d$ no data, + positive detection, - negative detection

${ }^{\mathrm{e}}$ Data on expression of human HSPA2 extracted from the BioGPS database; expression values obtained for 1417101_at probe set; $n d$ no data

${ }^{\mathrm{f}}$ Results of protein expression in mouse tissues according to Vydra et al. (2009); nd no data, + positive detection, - negative detection

("Function of HSPA2 in normal somatic and cancer cells" section).

An important issue facing HSPA researchers concerns obtaining antibodies highly specific for a particular member of the HSPA family. The major problem is cross-reactivity of a given anti-HSPA antibody with several HSPA proteins due to very high amino acid sequence similarity between them. This problem pertains even to commercial, commonly used anti-
HSPA antibodies (Chow et al. 2010; Scieglinska et al. 2011). Table 4 collects data on antibodies used for HSPA2 detection. So far, rabbit polyclonal anti-sera raised in accordance with a protocol developed by Rosario et al. (1992) against a short peptide derived from the C-terminal part (aa 611-628) of mouse HSPA2 have been the most commonly used (Son et al. 1999; Rohde et al. 2005; Daugaard et al. 2007; Scieglińska et al. 2008, 2011, 2014; Garg et al. 2010a, b). It 
Table 3 Summary on HSPA2 expression in cancer cell lines and human primary metastatic tumors

\begin{tabular}{|c|c|c|c|c|c|}
\hline Organ & Cell lines & $\begin{array}{l}\text { HSPA2 } \\
\text { expression } \\
\text { mRNA/protein }\end{array}$ & Tumors & HSPA2 (results of IHC) & Clinical significance \\
\hline Bladder & $\begin{array}{l}\text { Cancer: HTB- }{ }^{\text {a }}, \text { UMUC- }^{\text {a }} \text {, } \\
\text { HTB- } 9^{\mathrm{a}}, \text { HTB-2 } \\
\text { Normal urothelial cell line }\end{array}$ & $\begin{array}{l}+/+ \\
-/-\end{array}$ & Urothelial cancer & $\begin{array}{l}\text { Expression in } 80 \% \text { of tumors } \\
(n=116, \mathrm{PS})^{\mathrm{a}} \\
\text { Overexpression in } 21 \% \text { of } \\
\text { tumors }(n=19, \mathrm{TMA})^{\mathrm{i}}\end{array}$ & $\begin{array}{l}\text { Increased expression associated } \\
\text { with tumor progression }\end{array}$ \\
\hline Breast & $\begin{array}{l}\text { Cancer: MCF- } 7^{\mathrm{b}, \mathrm{c}, \mathrm{d}} \\
\text { Non-tumorigenic: HBL- } 100^{\mathrm{b}, \mathrm{c}, \mathrm{d}} \text {, } \\
\text { MCF-10 } 10^{\mathrm{b}, \mathrm{d}}\end{array}$ & $\begin{array}{l}+/+ \\
+/+\end{array}$ & Breast cancer & $\begin{array}{l}\text { Expression in } 63 \% \text { of tumors } \\
\quad(n=27, \text { TMA })^{\mathrm{i}}\end{array}$ & nd \\
\hline Cervix & $\begin{array}{l}\text { Cancer: } \mathrm{SiHa}^{\mathrm{e}}, \mathrm{CaSki}^{\mathrm{e}}, \mathrm{C}-33 \mathrm{~A}^{\mathrm{e}} \text {, } \\
\mathrm{HeLa}^{\mathrm{b}, \mathrm{c}, \mathrm{e}}\end{array}$ & $+/+$ & Cervical SCC & $\begin{array}{l}\text { Expression in } 86 \% \text { of tumors } \\
\quad(n=76, \mathrm{PS})^{\mathrm{b}}\end{array}$ & $\begin{array}{l}\text { Increased expression associated } \\
\text { with tumor progression }\end{array}$ \\
\hline Colon & $\begin{array}{l}\text { Cancer: LoVo- } 36^{\mathrm{b}} \\
\text { Cancer: HCT- } 116^{\mathrm{d}}\end{array}$ & $\begin{array}{l}-/ \mathrm{nd} \\
+/-\end{array}$ & Colon AC & $\begin{array}{l}\text { Expression in } 47 \% \text { of tumors } \\
\quad(n=17, \text { TMA })^{\mathrm{i}}\end{array}$ & nd \\
\hline Esophagus & nd & nd & Esophageal SCC & $\begin{array}{l}\text { Expression in } 75 \% \text { of tumors } \\
\quad(n=120, \mathrm{PS})^{\mathrm{k}}\end{array}$ & $\begin{array}{l}\text { Expression associated with primary } \\
\text { tumor, TNM stage, lymph node } \\
\text { metastases, and recurrence }{ }^{\mathrm{k}} \\
\text { Expression correlated with shorter } \\
\text { patients OS }\end{array}$ \\
\hline Germ cell & Teratocarcinoma: NTERA2 ${ }^{\mathrm{f}}$ & $\mathrm{nd} /+$ & nd & nd & nd \\
\hline \multirow[t]{2}{*}{ Liver } & Cancer: HepG2 $2^{\mathrm{d}, \mathrm{g}}$ & $--^{\mathrm{d}} \quad+_{/}+^{\mathrm{g}}$ & Liver HCC & $\begin{array}{l}\text { High expression in } 57 \% \text { of } \\
\quad \text { tumors }(n=119, \text { PS })^{\mathrm{j}}\end{array}$ & $\begin{array}{l}\text { Expression related to tumor size, } \\
\text { differentiation, and stage }\end{array}$ \\
\hline & Cancer: $\mathrm{HUH}^{\mathrm{b}}$ & $+/$ nd & & $\begin{array}{l}\text { Expression in } 17 \% \text { of tumors } \\
\quad(n=18, \text { TMA })^{\mathrm{i}}\end{array}$ & $\begin{array}{l}\text { High expression correlated with } \\
\text { shorter patients OS }\end{array}$ \\
\hline \multirow[t]{2}{*}{ Lung } & $\begin{array}{l}\text { Cancer: NCI-H1299d }, \text { A549 } \\
\text { NCI-H358 }\end{array}$ & $+/+$ & Lung NSCLC & $\begin{array}{l}\text { Expression in } 62 \% \text { of tumors } \\
\quad(n=85, \mathrm{PS})^{\mathrm{i}}\end{array}$ & $\begin{array}{l}\text { Nuclear expression associated } \\
\text { with histology and TNM stage }{ }^{\mathrm{i}}\end{array}$ \\
\hline & Non-tumorigenic: BEAC-2B ${ }^{\mathrm{d}}$ & $+/+$ & & & $\begin{array}{l}\text { High expression correlated with } \\
\text { shorter patients } \text { OS }^{\mathrm{i}}\end{array}$ \\
\hline Prostate & $\begin{array}{l}\text { Cancer: } \mathrm{PC} 3^{\mathrm{b}, \mathrm{h}} \\
\text { Non-tumorigenic: } \mathrm{PNT} 1 \mathrm{~A}^{\mathrm{b}}\end{array}$ & $\begin{array}{l}+/+ \\
+/+\end{array}$ & Prostate AC & $\begin{array}{l}\text { Expression in } 6 \% \text { of tumors } \\
\quad(n=16, \mathrm{TMA})^{\mathrm{i}}\end{array}$ & nd \\
\hline
\end{tabular}

$I H C$ immunohistochemistry, $P S$ paraffin-embedded postsurgical tumor samples, $T M A$ tissue microarray, $S C C$ squamous cell carcinoma, $A C$ adenocarcinoma, $H C C$ hepatocellular carcinoma, NSCLC non-small cell lung carcinoma, $O S$ overall survival, $n d$ no data, + positive detection, - negative detection

${ }^{a}$ Results according to Garg et al. 2010b

${ }^{\mathrm{b}}$ Results according to Rohde et al. 2005

${ }^{\mathrm{c}}$ Results according to Daugaard et al. 2007

${ }^{\mathrm{d}}$ Results according to Scieglińska et al. 2008

${ }^{\mathrm{e}}$ Results according to Garg et al. 2010a

${ }^{\mathrm{f}}$ Results according to Sasaki et al. 2008

${ }^{\mathrm{g}}$ Results according to Huang et al. 2009

${ }^{\mathrm{h}}$ Results according to Alekseev et al. 2011

${ }^{\mathrm{i}}$ Results according to Scieglinska et al. 2014

${ }^{\mathrm{j}}$ Results according to Fu et al. 2014

${ }^{\mathrm{k}}$ Results according to Zhang et al. 2013

is worth mentioning that, due to the presence of a glycine-rich 7 aa insertion (GGGGAGA after serine 623) in the C-terminal part of human HSPA2, a corresponding peptide should not be considered as an antigen for generation of anti-HSPA2 antibodies. This insertion makes the C-terminal part of human HSPA2 highly similar to other glycine-rich proteins (Scieglinska et al. 2011).

The antigen affinity purification of the rabbit polyclonal HSPA2 anti-serum, raised in accordance with Rosario's protocol, improved both the sensitivity and specificity of detection. Such purified anti-HSPA2 antibody showed no cross-reactivity with recombinant HSPA1, HSPA6, and HSPA8 (the most similar to HSPA2) proteins (Scieglińska et al. 2008, 2011). To the best of our knowledge, no extensive verification of the specificity of other anti-HSPA2 antibodies (Table 4), including possible cross-reaction with other HSPA members, has been published. 
Table 4 Examples of antibodies used for HSPA2 detection

\begin{tabular}{|c|c|c|c|c|}
\hline $\begin{array}{l}\text { Host/ } \\
\text { Clonality }\end{array}$ & Antigen & Purity & Source & Reference \\
\hline $\mathrm{R} / \mathrm{P}$ & $\begin{array}{l}\text { M, bovine thyroglobulin-conjugated } \\
\text { peptide (aa } 611-628)^{\mathrm{b}}\end{array}$ & - & Custom-made & $\begin{array}{l}\text { Son et al. (1999) }{ }^{\text {a }} \text {; Huszar et al. } \\
\quad(2000)^{\text {a }} \text {; Alekseev et al. (2009) }\end{array}$ \\
\hline $\mathrm{R} / \mathrm{P}$ & $\begin{array}{l}\text { M, bovine thyroglobulin-conjugated } \\
\text { peptide (aa } 611-628)^{\mathrm{b}}\end{array}$ & $\begin{array}{l}\text { Affinity purified using } \\
\text { protein extract from } \\
\text { human testis }\end{array}$ & Custom-made & Scieglinska et al. $(2008,2011,2014)$ \\
\hline $\mathrm{R} / \mathrm{P}$ & $\begin{array}{l}\text { M, ovalbumin-conjugated peptide } \\
\quad(\text { aa } 611-628)^{\mathrm{b}}\end{array}$ & - & Custom-made & $\begin{array}{l}\text { Rohde et al. (2005); Daugaard } \\
\text { et al. (2007) }\end{array}$ \\
\hline $\mathrm{R} / \mathrm{P}$ & $\begin{array}{l}\text { M, ovalbumin-conjugated peptide } \\
\quad(\text { aa } 611-628)^{\mathrm{b}}\end{array}$ & $\begin{array}{l}\text { Affinity purified using } \\
\text { protein } \mathrm{G}\end{array}$ & Custom-made & Garg et al. $(2010 a, b)$ \\
\hline $\mathrm{R} / \mathrm{P}$ & $\begin{array}{l}\mathrm{H} \text {, ovalbumin-conjugated peptide } \\
\quad(\text { aa } 611-627)^{\mathrm{c}}\end{array}$ & - & Custom-made & Huang et al. (2009) \\
\hline $\mathrm{R} / \mathrm{P}$ & $\begin{array}{l}\mathrm{H} \text {, sperm HSPA2 excised from } \\
\text { preparative 2-D gels }\end{array}$ & - & Custom-made & $\begin{array}{l}\text { Naaby-Hansen and Herr } \\
\text { (2010) }\end{array}$ \\
\hline $\mathrm{R} / \mathrm{P}$ & $\mathrm{H}$, protein fragment (aa 488-637) ${ }^{\mathrm{c}}$ & $\begin{array}{l}\text { Affinity purified using } \\
\text { antigen }\end{array}$ & $\begin{array}{l}\text { Sigma-Aldrich } \\
\text { (HPA000798) }\end{array}$ & Redgrove et al. (2013) \\
\hline $\mathrm{M} / \mathrm{P}$ & $\begin{array}{l}\mathrm{H} \text {, full-length recombinant protein } \\
\quad(\text { aa } 1-639)^{\mathrm{c}}\end{array}$ & Purified immunoglobulin & $\begin{array}{l}\text { Sigma-Aldrich } \\
\text { (SAB1405970) }\end{array}$ & Redgrove et al. (2013) \\
\hline $\mathrm{M} / \mathrm{Mo}$ & $\begin{array}{l}\mathrm{H} \text {, full-length recombinant protein } \\
\quad(\text { aa } 1-639)^{\mathrm{c}}\end{array}$ & Protein G purified & Abcam (ab55290) & $\begin{array}{l}\text { Alekseev et al. (2011); Wu } \\
\text { et al. (2011) }\end{array}$ \\
\hline $\mathrm{R} / \mathrm{P}$ & $\begin{array}{l}\mathrm{H} \text {, full-length HSPA2 isolated from } \\
\text { spermatozoa }\end{array}$ & - & Custom-made & Huszar et al. (2000) \\
\hline $\mathrm{M} / \mathrm{Mo}$ & $\mathrm{H}$, recombinant protein & - & Santa Cruz Biotech (JJ-3) & Zhang et al. (2013) \\
\hline $\mathrm{G} / \mathrm{P}$ & $\begin{array}{l}\mathrm{H} \text {, peptide mapping within internal } \\
\quad \text { region of HSPA2 (aa not specified) }\end{array}$ & Affinity purified & Santa Cruz Biotech (K-12) & Fu et al. (2014) \\
\hline
\end{tabular}

$H$ human, $M$ mouse, $G$ goat, $M o$ monoclonal, $P$ polyclonal, $R$ rabbit

${ }^{\text {a }}$ Anti-serum obtained by Rosario et al. 1992

${ }^{\mathrm{b}}$ NCBI Reference Sequence NP_001002012.1

${ }^{\mathrm{c}}$ NCBI Reference Sequence NP_068814.2

\section{Regulation of the expression of the HSPA2 gene}

DNA regulatory elements required for HSPA2 expression in rodent testis

The HSPA2 gene, initially classified as unique, testis-specific member of the HSPA family, was thus presumed to be under the control of factors specific for spermatogenic cells. In order to determine the DNA sequences required for such expression pattern, and due to lack of suitable in vitro models, we constructed TG mice bearing a transgene composed of a CAT reporter fused to various fragments of the rat HSPA2 gene promoter. This approach allowed to establish that a relatively short fragment of DNA ( -367 to $-203 \mathrm{nt}$ in relation to ATG) located directly downstream of the $\mathrm{T} 1$ transcription start site (within the non-coding exon 1) is sufficient to drive testisenriched and developmentally regulated expression of the transgene (Fig. 1). Within this region, we identified two short stretches which we termed box A (nt -346 to -325$)$ and box B (nt -260 to -235 ) sharing the highest degree of nucleotide sequence homology between the mouse and rat genes. These boxes were shown to be of critical importance for transgene expression in the testis of TG mice (Fig. 1; Widłak et al. 1994; Widłak et al. 1995; Dix et al. 1996b; Scieglinska et al. 2001, 2004; Widlak et al. 2007a).

A search for potential cis-regulatory elements within the box A region led to the identification of a consensus sequence for binding of Sp1 transcription factor (GC-box) and a sequence highly similar to the octamer-binding transcription factor 1 binding site (Oct1-like). In turn, within the box B region, we found an estrogen-responsive element (ERE)-like sequence which differed by one nucleotide from the ERE and a H1t-like motif highly similar to the sequence involved in regulation of the H1t gene expression. Downstream of the box $\mathrm{B}$ region, just in front of the T2 transcription start site, a second GC-box is placed. The localization of these regulatory elements in the HSPA2 promoter along with the results of the functional promoter analysis is summarized in Fig. 1.

Band shift analysis revealed that the testes of immature rats (9-10 days old), which do not express the HSPA2 gene, contain some protein(s) that specifically interacts with the Oct1-like motif and the GC-boxes, respectively (Scieglińska et al. 2004; Widlak et al. 2007a). This observation indicates that some, so far unidentified protein(s), may act as 

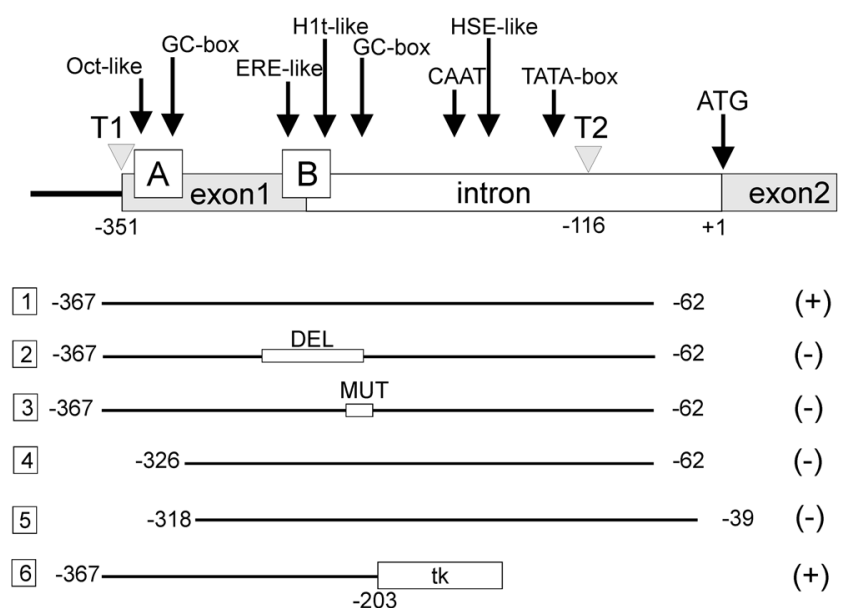

Fig. 1 Summary of results concerning functional analysis of the activity of the HSPA2 promoter in transgenic mice testes. The upper diagram shows the structure of the HSPA2 transcription unit. The potential sequences implicated in regulation of the HSPA2 gene expression in rodent tissues are indicated. Note that only the regulatory sequences that were subjected to functional studies are shown. T1 $(-353)$ and T2 (-116) transcription start sites. The bottom diagram shows the promoter fragments that were fused to a reporter gene and analyzed in transgenic mice testes. Transgene expression (positive); No transgene expression (negative). Activities of constructs 1 and 4 were reported in Scieglinska et al. (2001), those of constructs 2 and 3 were described in Widlak et al. (2007a), construct 5 was evaluated in Dix et al. (1996b), and finally, construct 6 was assessed in Scieglińska et al. (2004). Numbers are coordinates of DNA fragment position in relation to A $(+1)$ in the ATG translation start codon. $D E L$ deletion, MUT point mutations, $t k$ thymidine kinase promoter

repressor(s) of HSPA2 gene expression in spermatogonia and early spermatocytes. Therefore, it is possible that dissociation of these repressors from the HSPA2 promoter is a prerequisite for activation of the gene expression in pachytene spermatocytes. In regard to the TE-1 and ERE-like motifs of the box B, we found that these sequences are not involved in the regulation of HSPA2 gene expression in testis (Scieglińska et al. 2004; Krawczyk et al. 1992). In summary, the available data allow us to hypothesize that in spermatocytes, the HSPA2 gene could be under positive control of some general transcription factors (probably including their testis-specific variants). It is also probable that transcriptionally competent chromatin could be one of the main requirements for HSPA2 gene expression. Such a supposition is partially supported by the observation that the HSPA2 promoter is also active when present in an episomal form both in testicular and somatic cells (Widłak et al. 2003b; 2007a).

It is worth noting that the cis and trans elements involved in the HSPA2 gene regulation are still poorly characterized. However, the identification of the promoter fragment required for testis-enriched expression enabled construction of TG mice in which expression of various proteins, such as CAT (Widłak et al. 1995; Scieglinska et al. 2001), EGFP (Widłak et al. 2003b; Rupik et al. 2006), heat shock transcription factor HSF1 (Widłak et al. 2003a; Vydra et al. 2006), heat shock protein HSPA1 (Widlak et al. 2007c), or Cre recombinase (Inselman et al. 2010), was effectively targeted into spermatocytes.

Translational and posttranslational regulation of HSPA2 expression in rodent testis

Recent study has suggested that, in rodent testis, the expression of the HSPA2 gene could be regulated at the translational and posttranslational levels by mechanisms that engage several different proteins. Hu antigen R (HuR), an RNA-binding protein, is known to influence the translation of multiple mRNAs by binding to their $3^{\prime}$ untranslated region and (among others) controls stability of long-lived mRNAs that are translated at late stages of spermiogenesis (Nguyen Chi et al. 2009). Aberrant expression of HuR protein (either deficiency or overexpression) in mice testis led to defective spermatogenesis manifested by massive death of spermatocytes (Chi et al. 2011). It has been found that HuR supports the optimal binding of the HSPA2 mRNA to translating ribosomes in elongating spermatids and possibly also in pachytene spermatocytes (Chi et al. 2011).

HSPA2 expression in testis can be regulated at posttranslational level by proteins such as the following: the multifunctional Bat3 (HLA-B-associated transcript 3, also known as BAG6) chaperone belonging to BCL2-associated athanogene (BAG) domain protein family (Sasaki et al. 2008; Kawahara et al. 2013); HSPA binding protein HSPBP1, a nucleotide exchange factor of HSPA proteins and inhibitor of protein degradation mediated by the carboxy terminus of HSP70 interacting protein CHIP (Rogon et al. 2014); and eukaryotic translation initiation factor 4 gamma 3 (Eif4g3, Sun et al. 2010).

Bat3 and the co-chaperone HSPBP1 were shown to bind to HSPA2 and prevent its ubiquitination and proteasomal degradation in the testis (Sasaki et al. 2008; Rogon et al. 2014). Deficiency of Bat3, or HSPBP1, in knockout (KO) mice leads to male infertility caused by impaired spermatogenesis with morphological features similar to those observed in HSPA2 null mice. It turned out that in the testis of these two knock-out mice strains, the level of HSPA2 protein is significantly reduced (Sasaki et al. 2008; Rogon et al. 2014). Bearing in mind that HSPA2 is expressed in certain somatic cells, it would be important to elucidate to what extent HSPA2 expression in non-testicular cells could be regulated by controlled degradation. Such a Bat3-dependent regulatory mechanism seems to exist because depletion of Bat3 was associated with decreased stability of HSPA2 in mouse embryonic fibroblasts (MEFs) and human teratocarcinoma cells (Sasaki et al. 2008). Also, the CHIP inhibitors HSPBP1 and BAG2 were shown to jointly control the proteasomal degradation of HSPA2 in MEF cells (Rogon et al. 2014). 
Eif4g3, another protein which is supposed to modulate the level of HSPA2, is a multipurpose adapter connecting mRNA and ribosomes that acts as a scaffold protein for other factors involved in the formation of the initiation complex. Missense mutation in exon 36 of the mouse Eif4g3 gene causes a failure of spermatocytes to exit meiotic prophase. Interestingly, the HSPA2 protein is absent from spermatocytes of Eif4g3 mutant mice in spite of the presence of Bat 3 and normal levels of the HSPA 2 mRNA (Sun et al. 2010). These authors hypothesized that Eif4g3 could be engaged in the translation of some unidentified regulator(s) of HSPA2 protein stability or be involved in initiation of HSPA2 translation.

\section{Regulation of the HSPA2 gene in human tissues}

Mechanisms and factors that modulate the activity of the human HSPA2 gene are even less understood than its rodent counterparts. Functional promoter analysis revealed the 392nt-long DNA fragment localized directly upstream of the ATG codon to be the shortest promoter fragment sufficient to support transcription of the CAT reporter gene both in cancer cells expressing (A549) and non-expressing (HepG2) the endogenous HSPA2 gene (Piglowski et al. 2007). These results indicate that the transcription factors necessary to support the HSPA2 promoter activity at a basal level are contained in somatic cells irrespectively of the status of the endogenous gene activity, allowing speculation that epigenetic mechanisms could be of prime importance in the regulation of the HSPA2 gene expression.

The accumulating evidence points to DNA methylation as one of the most important epigenetic mechanisms modulating the HSPA2 expression level in human cells. HSPA2 gene methylation was detected in numerous breast, cervical, bladder, and renal cancer cell lines (Ye et al. 2012; Pulverer et al. 2012; Costa et al. 2010; Sova et al. 2006). Since treatment of cells with 5-azacytidine (a DNA methylation inhibitor) restored HSPA2 transcription to a high level (Ye et al. 2012; Sova et al. 2006), but hypermethylation induced the opposite effect (Costa et al. 2010), it seems probable that the methylation status of the HSPA2 gene correlates with its transcription level. In genome-wide studies designed to unveil new bladder cancer-specific epigenetic markers, the HSPA2 gene was found among the most frequently methylated genes both in bladder cancer cell lines and in primary bladder tumors, but not in normal urothelial tissue (Costa et al. 2010; Reinert et al. 2011). The frequent cancer-specific hypermethylation of the gene was also detected in endometrial and invasive cervical cancers (Fiegl et al. 2004; Widschwendter et al. 2004).

Although the above-mentioned observations strongly suggest that epigenetic modification could be important for regulation of HSPA2 gene expression, there are some controversies regarding this issue. While hypermethylation-related repression of the HSPA2 gene in primary bladder tumors has been reported (Costa et al. 2010; Reinert et al. 2011), others found the HSPA2 gene to be highly expressed in bladder cancer cell lines and in primary urothelial tumors (Garg et al. 2010b). Similar discrepancies have emerged in the case of HeLa (cervix) and MCF-7 (breast) cancer cell lines. Whereas high expression of the HSPA2 gene in these cells was reported by several groups (Rohde et al. 2005; Daugaard et al. 2007; Garg et al. 2010a), in other works, the HSPA2 gene was found to be hypermethylated and expressed at insignificant levels (Sova et al. 2006; Pulverer et al. 2012; Ye Ch et al. 2012). The reasons for these inconsistencies are unknown.

The HSPA2 gene expression in response to heat shock and hypoxia

In somatic cells exposed to heat shock, a subset of HSP genes is activated by binding of the HSF1 transcription factor to the regulatory heat shock elements (HSEs) present in promoters of stress-inducible genes. Rodent orthologs of the HSPA2 gene contain HSE-like sequence of low similarity to the canonical HSE and does not bind constitutively active mutant of HSF1 (Widlak et al. 2007b). The HSPA2 gene expression is not induced by heat shock in rodent spermatogenic and somatic cells (Krawczyk et al. 1988; Zakeri et al. 1988; Zakeri et al. 1990). Also, the human HSPA2 gene is not induced by heat shock (Scieglińska et al. 2008; Hageman et al. 2011), and no binding of HSF 1 to the HSPA2 promoter was detected in heatshocked human cells (Trinklein et al. 2004; Hageman et al. 2011; Vihervaara et al. 2013). Noteworthy, up-regulation of HSPA2 gene expression, likely mediated rather by HSF2 and not HSF1, was observed in K562 erythroleukemia cells upon treatment with hemin, a differentiation-inducing metabolite (Trinklein et al. 2004).

Increasing the temperature of rat testes by placing them in the abdominal cavity (experimental cryptorchidism) results in rapid disappearance of the HSPA2 mRNA and degeneration of seminiferous epithelium (Krawczyk et al. 1987a; Widlak et al. 2007b). Similarly, a marked reduction of the HSPA2 expression level occurred in parallel with rapid degeneration of seminiferous epithelium due to massive apoptosis of spermatocytes when the constitutively active mutant of HSF 1 was overexpressed in testes of transgenic mice (Nakai et al. 2000; Widłak et al. 2003a; Vydra et al. 2006). At present, the mechanism by which HSF1 affects HSPA2 gene expression is unknown. HSF1 could possibly suppress some genes which encode so far unidentified factors crucial for HSPA2 expression in testis (Widlak et al. 2007b). The detrimental influence of HSF 1 on the seminiferous epithelium demonstrates that the response of somatic and spermatogenic cells to heat shock is clearly different. This dissimilarity also manifests itself in the observation that the forced overexpression of HSPA1 in spermatocytes of TG mice shows no protective effect against 
apoptosis induced either by experimental cryptorchidism or by overexpression of active HSF1 (Widlak et al. 2007c).

The study of cancer cells pointed to the possible activation of the HSPA2 expression by hypoxia, a condition frequently associated with tumor propagation. In fact, hypoxia increased the HSPA2 expression in human hepatoma (HepG2), breast (MCF-7), and cervical (HeLa) cancer cells. Functional promoter studies and chromatin immunoprecipitation assays confirmed that the activation of the HSPA2 gene was mediated by interaction of hypoxia-inducible factor (HIF)-1 transcription factor with the hypoxia-responsive element (HRE) localized at 446-bp upstream of the transcription start site (Huang et al. 2009). Our recent study revealed that HSPA2 gene expression can also be modulated by HIF-1 and hypoxia in keratinocytes, but in contrast to HepG2 cells, both primary keratinocytes and the immortal human keratinocyte line $\mathrm{HaCaT}$ respond to hypoxia by a significant decrease in the HSPA2 gene expression level (our unpublished results). This observation seems relevant in the context of a crucial role of HIF-1 in the maintenance of skin homeostasis (Cho et al. 2008; Rezvani et al. 2011). Physiological oxygen pressure in the epidermis ranges between 0.2 and $8 \%$, and thus, moderate hypoxia is a physiological condition during growth and differentiation of keratinocytes (Rezvani et al. 2011; Evans et al. 2006). Consequently, one can assume that HIF-1-dependent modulation of HSPA2 gene expression in keratinocytes might be related to normal processes of development/differentiation of skin epithelium.

\section{Function of the HSPA2 protein in spermatogenesis}

Phenotype analysis of HSPA2 KO mice led to the conclusion that the HSPA2 gene is crucial for male, but not female, fertility (Dix et al. 1996a). HSPA2 deficiency led to severe degeneration of seminiferous epithelium manifested by massive apoptosis of pachytene spermatocytes and lack of postmeiotic cells (Dix et al. 1996a, 1997). Profiling the expression of molecular markers specific for defined stages of spermatogenesis established that HSPA2 depletion severely impaired the late stages of spermatocyte development (Dix et al. 1997).

The HSPA2 protein was found to localize along the structures formed by synaptonemal complexes in pachytene spermatocytes of wild-type mice (Allen et al. 1996). Microscopic observation of the testis of HSPA2 null mice suggested that HSPA2 is required for desynapsis of synaptonemal complexes (Dix et al. 1997). In HSPA2 KO males, spermatogenesis arrested at $\mathrm{G} 2 / \mathrm{M}$ and did not progress to the $\mathrm{M}$ stage of meiosis. Subsequent analysis revealed that HSPA2 is indispensably required for the formation of the cyclin-dependent kinase 1 (CDK1)/cyclin B1 complex in spermatocytes and confirmed its essential role for progression of meiosis. HSPA2 was found to interact with $\mathrm{CDK} 1$, but not with cyclin $\mathrm{B}$, and only when the kinase was not complexed with cyclin B1 (Zhu et al. 1997).

The HSPA2-dependent regulation of CDK1/cyclin B1 activity seems to be modulated by at least two proteins: H1t, a testis-specific variant of linker histone H1, and tNASP, a testis/embryo form of nuclear autoantigenic sperm protein (Alekseev et al. 2009). The latter belongs to a family of specific histone chaperones which facilitate the incorporation of linker histones into chromatin and enable the progression of the cell cycle through the G1/S border (Finn et al. 2012). Intriguing data indicate the occurrence of interaction between tNASP, H1t, HSPA2, and CDK1 in mouse spermatocytes. H1t binds to the tNASP-HSPA2 complex. This interaction enhances weak intrinsic HSPA2 ATPase activity, increases the ability of HSPA2 to tether CDK1, and concomitantly prevents the binding of cyclin B1 to HSPA2/CDK1 complexes. Altogether, the coordinated action of tNASP and histone H1t modulates the ability of HSPA2 to form an active CDK1/ cyclin $\mathrm{B} 1$ complex and regulates the progression of meiosis (Alekseev et al. 2009).

Experimental data suggest that during mouse spermiogenesis, HSPA2 also participates in the chromatin condensation. At the beginning of this multistage process, both core and linker histones are replaced by their testis-specific variants. Concomitant, massive hyperacetylation of chromatin is believed to destabilize its nucleosomal structure and to facilitate the replacement of testis-specific histones by transition proteins (TPs) and finally by other basic DNA-packaging proteins (Gaucher et al. 2010). Proteomic analysis and microscopic visualization revealed that in elongating spermatids, HSPA 2 undergoes redistribution from a dispersed intranuclear location to subacrosomal domains, and these changes correlated with the cessation of histone acetylation and histone removal (Govin et al. 2006). Detection of complexes containing TP1, TP2, and HSPA2 led to the conclusion that HSPA2 performs a role of a specific chaperone for DNA-packaging TPs, being involved in the assembly of new spermatidspecific nuclear structures (Govin et al. 2006).

The HSPA2-dependent replacement of histones by TP is supposed to be modulated by poly(ADP-ribose) polymerases PARP-1 and PARP-2. These enzymes belong to the large PARP family, members of which contribute to the epigenetic regulation of various physiological processes including chromatin reorganization during spermiogenesis (Dantzer et al. 2006; Quenet et al. 2009; Meyer-Ficca et al. 2009). Mass spectrometry analysis revealed that in mouse spermatids, PARP-2 interacts with HSPA2 in a TP2-dependent manner and PARP-1 modifies HSPA2 structure by ADP-ribosylation (Quenet et al. 2009). These results suggest that HSPA2, together with TP2, PARP-1, and PARP-2, could form spermatid-specific complex(es), presumably of crucial 
importance for chromatin remodeling. Likely, coordinated processes of PARP-1-dependent poly(ADP-ribosyl)ation of HSPA2, PARP-2-dependent poly(ADP-ribosyl)ation of TP, and chaperoning activity of HSPA2 exerted on TP2 and TP1 might contribute to chromatin reorganization and formation of spermatozoa (Quenet et al. 2009).

There is some indirect evidence implying that the spermatid-specific chromatin remodeling can be affected by phosphorylation of HSPA2. According to the PhosphoSitePlus (http://phosphosite.org) database, HSPA2 can be phosphorylated at some serine and threonine residues in vivo. Moreover, HSPA2 was found to be among potential targets of serine/threonine phosphoprotein phosphatase 1 gamma 2 (PPP1CC2; Henderson et al. 2011). Expression of PPP1CC2, one of the two alternatively spliced isoforms encoded by the Ppplcc gene, is restricted to spermatogenic cells. Disruption of the Ppplcc gene results in aberrant spermiogenesis manifested by abnormal chromatin packing (histone retention), increased germ cell apoptosis, and, consequently, deficiency of condensing and elongating spermatids (Varmuza et al. 1999; Forgione et al. 2010). Taking into account that PPP1CC2 can directly interact with HSPA2 and PPP1CC2 depletion leads to the accumulation of hyperphosphorylated HSPA2 in testis, it was proposed that the PPP1CC2-dependent modulation of HSPA2 structure/ activity could contribute to chromatin remodeling during spermiogenesis in mouse (Henderson et al. 2011).

The above data suggest that in mice (and possibly in other rodents), posttranslational modifications of HSPA2 could be crucial for the process of chromatin remodeling, presumably switching the ability of HSPA2 to interact with specific client proteins during different stages of spermiogenetic maturation. Such an intriguing possibility should be however experimentally verified.

A number of biochemical and clinical observations show that also in humans, expression of the HSPA2 gene is required for male fertility. However, the results of studies published so far suggest that the expression pattern and functions of HSPA2 in rodent and human spermatogenesis may not fully overlap. In the human testis, HSPA2 is expressed at a significantly higher level in elongating spermatids and spermatozoa than in spermatocytes (Huszar et al. 2000; Motiei et al. 2013; Redgrove et al. 2012). So far, neither the role of human HSPA2 in the dissociation of the synaptonemal complex nor its chaperoning activity exerted on the components of cyclin-CDK complexes has been documented. Instead, adequate evidence points to a crucial role of HSPA2 in spermiogenetic maturation and sperm ability to fertilize an oocyte.

Early studies linked the reduced levels of HSPA2 (initially described as an unusual variant of creatinine kinase $M$ ) with aberrant spermiogenetic maturation and production of nonfunctional sperm characterized by retention of cytoplasm, aberrant plasma membrane remodeling, and lack of zona pellucida (ZP) binding sites (Huszar et al. 2000; Huszar et al. 1997; Huszar et al. 1998). Low level of HSPA2 was also correlated with increased aneuploidy frequencies in immature sperm. The type of aneuploidy (disomies) allowed to speculate that low HSPA2 expression might be related to impaired meiotic division of human spermatocytes (Kovanci et al. 2001).

In subsequent studies, reduced expression of the HSPA2 gene was found in the testes or in spermatozoa of men with abnormal spermatogenesis (Feng et al. 2001; Cedenho et al. 2006; Lima et al. 2006; Terribas et al. 2010). In infertile men, also a low number of HSPA2-positive sperm were detected (Motiei et al. 2013). Recently, an association between impaired fertilizing ability of sperm from patients diagnosed with idiopathic male infertility and a total lack of HSPA2 in their sperm has been reported (Redgrove et al. 2012).

There are discrepancies between results on HSPA2 localization in sperm. Motiei et al. (2013) have shown that sperm maturation is associated with rearrangements of HSPA2 localization from intracellular in non-capacitated sperm, to superficial in capacitated spermatozoa. Other group has shown that HSPA2 localizes solely in intracellular sperm compartments regardless of the capacitation status (Redgrove et al. 2012; 2013). However, despite these controversies, it seems evident that HSPA2 is important for sperm-egg recognition. Early studies demonstrated that a reduced level of HSPA2 in spermatozoa is manifested by decreased ability of sperm to interact with oocyte and to fertilize it (Huszar et al. 1994). Diminished sperm HSPA2 levels were shown to predict in vitro fertilization failure (Ergur et al. 2002). According to recent studies performed by Redgrove et al. (2012; 2013), HSPA2 is a component of a multimeric sperm-egg recognition complex which contains sperm adhesion molecule 1 (SPAM1) and arylsulfatase A (ARSA) proteins, both previously implicated in sperm-oocyte interactions. The authors proposed that SPAM1 is positioned on the membrane of non-capacitated sperm to mediate binding and dispersion of the hyaluronicrich matrix of the cumulus mass. As sperms penetrate the cumulus mass and finish capacitation, the complex is reoriented to express ARSA, one of the putative receptors for the ZP. In this model, HSPA2 is localized intracellularly, and its activity could provide a driving force for SPAM1 and ARSA movements. Investigation of the dynamic structure of the HSPA2/ARSA/SPAM1 complex also pointed to potential capacitation-dependent phosphorylation of HSPA2 mediated via activity of protein kinase A (Redgrove et al. 2013). This further implies that posttranslational modifications of HSPA2 could have a crucial impact on its activity. Although the results cited above point to an essential role for HSPA2 in the sperm-egg recognition process, a comprehensive understanding of its function in the fertilization process still requires further studies. 


\section{Function of HSPA2 in normal somatic and cancer cells}

At present, the function of HSPA2 in human somatic cells is poorly characterized and can be only inferred from a few studies. Two recent studies have demonstrated that HSPA2 exhibits chaperoning and cytoprotective activity. Hageman et al. (2011) have shown that overexpression of HSPA2 in human embryonic kidney HEK-293 cells enhanced refolding of heat-denatured luciferase and suppressed formation of luciferase aggregates in heat-shocked cells. We have reported that overexpression of HSPA2 in Chinese hamster lung fibroblasts (V79 cells) increased the resistance of cells to apoptosis induced by heat shock or proteasome inhibitors (Filipczak et al. 2012). Interestingly, HSPA2 did not protect cells against toxic effects caused by the microtubule-affecting drugs vinblastine and paclitaxel or by the DNA-intercalating topoisomerase II inhibitor doxorubicin. Therefore, one can speculate that HSPA2 has selective cytoprotective activity. HSPA2 could also influence the function/structure (but not stability) of lysosomal/endosomal membranes. Such a supposition emerged from the observation that extracellularly supplied recombinant HSPA2 co-localized with markers specific for late endosomes and lysosomes (Kirkegaard et al. 2010).

Although expression of the HSPA2 gene is not induced by heat shock (Scieglińska et al. 2008; Hageman et al. 2011), a sudden increase in temperature causes rapid translocation of HSPA2 from the cytoplasm into the nuclei and nucleoli as well as into the area of centrosomes (Scieglińska et al. 2008). Such a pattern of HSPA2 translocation is similar to that observed for the heat-inducible HSPA1 and HSPA6 proteins (Pelham 1984; Hut et al. 2005; Khalouei et al. 2014). This suggests that HSPA2 may participate in the protection of nucleolus and/or centrosome integrity under conditions of thermal (and possibly other) stress(es) (Scieglińska et al. 2008), as suggested earlier for HSPA1 (Pelham 1984; Hut et al. 2005).

The majority of the knowledge on the HSPA2 function in cancer cells has been inferred from studies in which the expression of the HSPA2 gene was silenced by RNA interference (RNAi) technology (Rohde et al. 2005; Daugaard et al. 2007; Garg et al. 2010a; 2010b). The earliest studies revealed that even single transfection of HeLa or MCF-7 cells with siRNA targeted against HSPA2 mRNA induced a senescencelike phenotype and G1 cell cycle arrest followed by apoptosislike cell death (Rohde et al. 2005; Daugaard et al. 2007). Because HSPA2 depletion had no effect on proliferation of non-cancerous immortalized epithelial cells derived from breast or prostate epithelia, it has been concluded that HSPA2 is specifically required for growth of cancer cells (Rohde et al. 2005). The importance of HSPA2 for cancer cell proliferation has been underlined by observations showing reduced growth of human urothelial and cervical cancers cells in response to HSPA2 depletion (Garg et al. 2010a, b).
Moreover, Garg et al. (2010a, b) reported that HSPA2 knockdown decreased migration of cancer cells.

The results described above are in contrast with the effects of HSPA2 depletion in non-small cell lung cancer (NSCLC) cell lines that were obtained by our group. By stably infecting NSCLC cells using viral vectors (lentiviruses or retroviruses) encoding small hairpin RNAs (shRNAs), we effectively reduced HSPA2 gene expression by up to $90 \%$ of the controls (non-infected or infected with scrambled shRNA). However, no effects on cell viability have been detected in HSPA2depleted cells (Scieglinska et al., unpublished). Because each study cited above exploited a different cancer cell line and different gene silencing strategies, it is evident that more systematic studies are needed in order to understand the cause of the variable effects of HSPA2 deficit on growth of cancer cells.

One of the most intriguing issues concerning the potential influence of HSPA2 on the phenotype of tumor cells emerges from the comparison of the HSPA2 expression pattern in primary tumors and in the corresponding normal tissues (Rohde et al. 2005; Garg et al. 2010b; Scieglinska et al. 2014). In the case of certain tumors, as exemplified by breast and bladder cancers, HSPA2 can be detected in tumor but not in the corresponding normal tissue (Garg et al. 2010b; Scieglinska et al. 2011, 2014). It therefore seems evident that in these cases, the expression of the HSPA2 gene is initiated during tumor development. On the other hand, HSPA2 expression can be detected at comparable levels both in tumor and corresponding normal tissue as exemplified by lung squamous cell cancer (SCC) tumors and normal bronchial epithelium (Scieglinska et al. 2011, 2014). Thus, one can presume that oncogenic transformation from normal bronchial epithelium to SCC lung cancer is accompanied by continued expression of the HSPA2 gene (Scieglinska et al. 2011). Finally, all of the observations above allow to propose that HSPA2 could play different roles in various types of cancer, depending on whether this protein was expressed in cancer precursors or its expression was acquired during oncogenic transformation.

Another interesting aspect of the HSPA2 expression in tumors concerns possible functional differences between this protein and HSPA1, another member of the HSPA family. HSPA1 is a major stress-inducible protein which is frequently overexpressed in various tumors. A selective silencing of either HSPA2 or HSPA1 in HeLa cells resulted in distinct phenotypes. While HSPA2-depleted cells acquired a senescent-like phenotype and were arrested in G1 of the cell cycle, silencing of the HSPA1 gene resulted in G2/M arrest and immediate entry of cells into apoptosis. Also, a global transcriptome analysis of HeLa cells revealed strikingly distinct changes in gene expression between HSPA2- and HSPA1-depleted cancer cells (Rohde et al. 2005; Daugaard et al. 2007). These observations suggest that HSPA2 and 
HSPA1 exhibit substantial functional diversity and, possibly, they can be a part of distinct functional networks and/or they can interact with diverse arrays of client proteins.

The role of HSPA2 in rodent somatic cells is entirely unknown. Expression of the HSPA2 gene was observed in major developmental events occurring during mouse embryogenesis (Murashov and Wolgemuth 1996a; Rupik et al. 2006). Although these results would indicate an involvement of HSPA2 in multiple processes during mouse embryogenesis, the deletion of the HSPA2 gene from mouse genome was not associated with reduced litter size, developmental abnormalities in newborn mice, or increased perinatal mortality as shown earlier by Dix et al. (1996a), indicating that HSPA2 is dispensable for mouse embryo development. At present, the cause of this apparent discrepancy is hard to explain. Since the HSPA2 protein has been found in embryonic mouse tissues, one can assume that the HSPA2 deficiency during development of HSPA2 KO mice could be substituted by other structurally and functionally similar protein(s).

\section{Concluding remarks}

The features of the HSPA2 gene, although it has been studied for more than 25 years, are still poorly characterized. Presumably, the reason is the long-lasting conviction that the HSPA2 gene is selectively involved in sperm cell differentiation, maturation, and activity. The recent studies have demonstrated, however, that the HSPA2 gene can be expressed at a relatively high level in selected populations of somatic cells. These findings allow us to assume that HSPA2 may have some, yet unidentified, functions (possibly including behavioral or cognitive) that cannot be directly inferred from observations of HSPA2 KO mice. Recent studies clearly show that the level of HSPA expression can be regulated by epigenetic (promoter methylation) and posttranscriptional mechanisms.

The intriguing issue concerns the role of the HSPA2 gene in human tumor cells. Although the expression of the HSPA2 gene in tumors is unquestionable, the influence of HSPA2 on the phenotype of cancer cells has not been unequivocally established. One of the most important issues is to determine to what extent HSPA2 influences survival and proliferation of cells of various cancer histotypes. So far, in numerous studies aimed at correlating the constitutive expression of HSPA (e.g., HSPA1 and HSPA8) with clinical features, the possible coexpression of the HSPA2 gene was, for obvious reasons, not taken into consideration. Bearing in mind that these proteins share several properties, the question concerning the similarity of their influence on cancer cell proliferation, resistance to cell death signaling, immunogenic properties, etc. is important. A clear answer to this question can be critical for verification of the potential usefulness of HSPA2, as well as other HSPA proteins, as clinical biomarkers. So far, there are no data concerning HSPA2 expression in tumors and tumor cells of rats and mice. Thus, it is unknown whether rodent models (except xenografts) would be suitable to study the role of HSPA2 in cancerogenesis. We hope that the data summarized in this review show clearly that HSPA2 represents an intriguing multifunctional member of the HSPA family.

Acknowledgments We thank Dr. Ronald Hancock, Dr. Wieslawa Widlak, and Dr. Aleksander Sochanik for helpful comments on the manuscript. This research is supported by grants DEC-2013/09/B/NZ5/ 01815 and NN401 683740 from the National Science Centre, Poland.

Open Access This article is distributed under the terms of the Creative Commons Attribution License which permits any use, distribution, and reproduction in any medium, provided the original author(s) and the source are credited.

\section{References}

Alekseev OM, Richardson RT, O'Rand G (2009) Linker histones stimulate HSPA2 ATPase activity through NASP binding and inhibit $\mathrm{CDC} 2 /$ cyclin $\mathrm{B} 1$ complex formation during meiosis in the mouse. Biol Reprod 81:739-748

Alekseev OM, Richardson RT, Tsuruta JK, O'Rand MG (2011) Depletion of the histone chaperone tNASP inhibits proliferation and induces apoptosis in prostate cancer PC-3 cells. Reprod Biol Endocrinol 9: 50

Allen JW, Dix DJ, Collins BW, Merrick BA, He C, Selkirk JK et al (1996) HSP70-2 is part of the synaptonemal complex in mouse and hamster spermatocytes. Chromosoma 104:414-421

Bonnycastle LL, Yu CE, Hunt CR, Trask BJ, Clancy KP, Weber JL et al (1994) Cloning, sequencing, and mapping of the human chromosome 14 heat shock protein gene (HSPA2). Genomics 23:85-93

Brocchieri L, Conway de Macario E, Macario AJ (2008) hsp70 genes in the human genome: conservation and differentiation patterns predict a wide array of overlapping and specialized functions. BMC Evol Biol 8:19

Cedenho AP, Lima SB, Cenedeze MA, Spaine DM, Ortiz V, Oehninger S (2006) Oligozoospermia and heat-shock protein expression in ejaculated spermatozoa. Hum Reprod 21:1791-1794

Chi MN, Auriol J, Jégou B, Kontoyiannis DL, Turner JM, de Rooij DG et al (2011) The RNA-binding protein ELAVL1/HuR is essential for mouse spermatogenesis, acting both at meiotic and postmeiotic stages. Mol Biol Cell 22:2875-2885

Cho YS, Bae JM, Chun YS, Chung JH, Jeon YK, Kim IS et al (2008) HIF-1alpha controls keratinocyte proliferation by up-regulating p21(WAF1/Cip1). Biochim Biophys Acta 1783:323-333

Chow AM, Mok P, Xiao D, Khalouei S, Brown IR (2010) Heteromeric complexes of heat shock protein 70 (HSP70) family members, including Hsp70B', in differentiated human neuronal cells. Cell Stress Chaperones 15:545-553

Ciocca DR, Arrigo AP, Calderwood SK (2013) Heat shock proteins and heat shock factor 1 in carcinogenesis and tumor development: an update. Arch Toxicol 87:19-48

Costa VL, Henrique R, Danielsen SA, Duarte-Pereira S, Eknaes M, Skotheim RI et al (2010) Three epigenetic biomarkers, GDF15, TMEFF2, and VIM, accurately predict bladder cancer from DNAbased analyses of urine samples. Clin Cancer Res 16:5842-5851

Dantzer F, Mark M, Quenet D, Scherthan H, Huber A, Liebe B et al (2006) Poly(ADP-ribose) polymerase-2 contributes to the fidelity of 
male meiosis I and spermiogenesis. Proc Natl Acad Sci U S A 103: 14854-14859

Daugaard M, Kirkegaard-Sørensen T, Ostenfeld MS, Aaboe M, HøyerHansen M, Orntoft TF et al (2007) Lens epithelium-derived growth factor is an Hsp70-2 regulated guardian of lysosomal stability in human cancer. Cancer Res 67:2559-2567

Dix DJ, Allen JW, Collins BW, Mori C, Nakamura N, Poorman-Allen P et al (1996a) Targeted gene disruption of Hsp70-2 results in failed meiosis, germ cell apoptosis, and male infertility. Proc Natl Acad Sci U S A 93:3264-3268

Dix DJ, Rosario-Herrle M, Gotoh H, Mori C, Goulding EH, Barrett CV et al (1996b) Developmentally regulated expression of Hsp70-2 and a Hsp70-2/lacZ transgene during spermatogenesis. Dev Biol 174: 310-321

Dix DJ, Allen JW, Collins BW, Poorman-Allen P, Mori C, Blizard DR et al (1997) HSP70-2 is required for desynapsis of synaptonemal complexes during meiotic prophase in juvenile and adult mouse spermatocytes. Development 124:4595-4603

Ergur AR, Dokras A, Giraldo JL, Habana A, Kovanci E, Huszar G (2002) Sperm maturity and treatment choice of in vitro fertilization (IVF) or intracytoplasmic sperm injection: diminished sperm HspA2 chaperone levels predict IVF failure. Fertil Steril 77:910-918

Evans SM, Schrlau AE, Chalian AA, Zhang P, Koch CJ (2006) Oxygen levels in normal and previously irradiated human skin as assessed by EF5 binding. J Investig Dermatol 126:2596-2606

Feng HL, Sandlow JI, Sparks AE (2001) Decreased expression of the heat shock protein hsp70-2 is associated with the pathogenesis of male infertility. Fertil Steril 76:1136-1139

Fiegl H, Gattringer C, Widschwendter A, Schneitter A, Ramoni A, Sarlay D et al (2004) Methylated DNA collected by tampons - a new tool to detect endometrial cancer. Cancer Epidemiol Biomarkers Prev 13:882 888

Filipczak PT, Piglowski W, Glowala-Kosinska M, Krawczyk Z, Scieglinska D (2012) HSPA2 overexpression protects V79 fibroblasts against bortezomib-induced apoptosis. Biochem Cell Biol 90:224-231

Finn RM, Ellard K, Eirin-Lopez JM, Ausio J (2012) Vertebrate nucleoplasmin and NASP: egg histone storage proteins with multiple chaperone activities. FASEB J 26:4788-4804

Forgione N, Vogl WA, Varmuza S (2010) Loss of protein phosphatase 1cc (PPP1CC) leads to impaired spermatogenesis associated with defects in chromatin condensation and acrosome development: an ultrastructural analysis. Reproduction 139:1021-1029

Fu Y, Zhao H, Li XS, Kang HR, Ma JX, Yao FF et al (2014) Expression of HSPA2 in human hepatocellular carcinoma and its clinical significance. Tumour Biol. doi:10.1007/s13277-014-2430-y

Garg M, Kanojia D, Saini S, Suri S, Gupta A, Surolia A et al (2010a) Germ cell-specific heat shock protein 70-2 is expressed in cervical carcinoma and is involved in the growth, migration, and invasion of cervical cells. Cancer 116:3785-3796

Garg M, Kanojia D, Seth A, Kumar R, Gupta A, Surolia A et al (2010b) Heat-shock protein 70-2 (HSP70-2) expression in bladder urothelial carcinoma is associated with tumour progression and promotes migration and invasion. Eur J Cancer 46:207-215

Gaucher J, Reynoird N, Montellier E, al Boussouar F, Rousseaux S, Khochbin S (2010) From meiosis to postmeiotic events: the secrets of histone disappearance. FEBS J 277:599-604

Gidalevitz T, Prahlad V, Morimoto RI (2011) The stress of protein misfolding: from single cells to multicellular organisms. Cold Spring Harb Perspect Biol 3:a009704

Govin J, Caron C, Escoffier E, Ferro M, Kuhn L, Rousseaux S et al (2006) Post-meiotic shifts in HSPA2/HSP70.2 chaperone activity during mouse spermatogenesis. J Biol Chem 281:37888-37892

Hageman J, van Waarde MA, Zylicz A, Walerych D, Kampinga HH (2011) The diverse members of the mammalian HSP70 machine show distinct chaperone-like activities. Biochem J 435:127-142
Henderson H, Macleod G, Hrabchak C, Varmuza S (2011) New candidate targets of protein phosphatase-1c-gamma-2 in mouse testis revealed by a differential phosphoproteome analysis. Int J Androl 34:339 351

Huang WJ, Xia LM, Zhu F, Huang B, Zhou C, Zhu HF et al (2009) Transcriptional upregulation of HSP70-2 by HIF-1 in cancer cells in response to hypoxia. Int J Cancer 124:298-305

Huszar G, Vigue L, Oehninger S (1994) Creatine kinase immunocytochemistry of human sperm-hemizona complexes: selective binding of sperm with mature creatine kinase-staining pattern. Fertil Steril 61:136-142

Huszar G, Sbracia M, Vigue L, Miller DJ, Shur BD (1997) Sperm plasma membrane remodeling during spermiogenetic maturation in men: relationship among plasma membrane beta 1,4galactosyltransferase, cytoplasmic creatine phosphokinase, and creatine phosphokinase isoform ratios. Biol Reprod 56:1020-1024

Huszar G, Patrizio P, Vigue L, Willets M, Wilker C, Adhoot D et al (1998) Cytoplasmic extrusion and the switch from creatine kinase B to M isoform are completed by the commencement of epididymal transport in human and stallion spermatozoa. J Androl 19:11-20

Huszar G, Stone K, Dix D, Vigue L (2000) Putative creatine kinase Misoform in human sperm is identified as the 70-kilodalton heat shock protein HspA2. Biol Reprod 63:925-932

Hut HM, Kampinga HH, Sibon OC (2005) Hsp70 protects mitotic cells against heat-induced centrosome damage and division abnormalities. Mol Biol Cell 16:3776-3785

Inselman AL, Nakamura N, Brown PR, Willis WD, Goulding EH, Eddy EM (2010) Heat shock protein 2 promoter drives Cre expression in spermatocytes of transgenic mice. Genesis 48:114-220

Kakkar V, Meister-Broekema M, Minoia M, Carra S, Kampinga HH (2014) Barcoding heat shock proteins to human diseases: looking beyond the heat shock response. Dis Model Mech 7:421-434

Kampinga H, Hageman J, Vos MJ, Kubota H, Tanguay RM, Bruford EA et al (2009) Guidelines for the nomenclature of the human heat shock proteins. Cell Stress Chaperones 14:105-111

Kawahara H, Minami R, Yokota N (2013) BAG6/BAT3: emerging roles in quality control for nascent polypeptides. J Biochem 153:147-160

Khalouei S, Chow AM, Brown IR (2014) Stress-induced localization of HSPA6 (HSP70B') and HSPA1A (HSP70-1) proteins to centrioles in human neuronal cells. Cell Stress Chaperones 19:321-327

Kirkegaard T, Roth AG, Petersen NH, Mahalka AK, Olsen OD, Moilanen I et al (2010) Hsp70 stabilizes lysosomes and reverts Niemann-Pick disease-associated lysosomal pathology. Nature 463:549-553

Kovanci E, Kovacs T, Moretti E, Vigue L, Bray-Ward P, Ward DC et al (2001) FISH assessment of aneuploidy frequencies in mature and immature human spermatozoa classified by the absence or presence of cytoplasmic retention. Hum Reprod 16:1209-1217

Krawczyk Z, Szymik N (1989) Effect of age and busulphan on the hsp70 gene-related transcript in rat testes. Int J Androl 12:72-79

Krawczyk Z, Szymik N, Wiśniewski J (1987a) Expression of hsp70related gene in developing and degenerating rat testis. Mol Biol Rep 12:35-41

Krawczyk Z, Wiśniewski J, Biesiada E (1987b) A hsp70-related gene is constitutively highly expressed in testis of rat and mouse. Mol Biol Rep 12:27-34

Krawczyk Z, Mali P, Parvinen M (1988) Expression of a testis-specific hsp70 gene-related RNA in defined stages of rat seminiferous epithelium. J Cell Biol 107:1317-1323

Krawczyk Z, Schmid W, Harkonen P, Wolniczek P (1992) The ERE-like sequences from the promoter region of the testis specific hsp70related gene is not estrogen responsive. Cell Biol Int Rep 16:937948

Lima SB, Cenedeze MA, Bertolla RP, Filho PA, Oehninger S, Cedenho AP (2006) Expression of the HSPA2 gene in ejaculated spermatozoa from adolescents with and without varicocele. Fertil Steril 86:16591663 
Matsumoto M, Fujimoto H (1990) Cloning of a hsp70-related gene expressed in mouse spermatids. Biochem Biophys Res Commun 166:43-49

Meyer-Ficca ML, Lonchar J, Credidio C, Ihara M, Li Y, Wang ZQ et al (2009) Disruption of poly(ADP-ribose) homeostasis affects spermiogenesis and sperm chromatin integrity in mice. Biol Reprod 81: $46-55$

Motiei M, Tavalaee M, Rabiei F, Hajihosseini R, Nasr-Esfahani MH (2013) Evaluation of HSPA2 in fertile and infertile individuals. Andrologia 45:66-72

Murashov AK, Wolgemuth DJ (1996a) Distinct transcripts are recognized by sense and antisense riboprobes for a member of the murine HSP70 gene family, HSP70.2, in various reproductive tissues. Mol Reprod Dev 43:17-24

Murashov AK, Wolgemuth DJ (1996b) Sense and antisense transcripts of the developmentally regulated murine hsp 70.2 gene are expressed in distinct and only partially overlapping areas in the adult brain. Brain Res Mol Brain Res 37:85-95

Naaby-Hansen S, Herr JC (2010) Heat shock proteins on the human sperm surface. J Reprod Immunol 84:32-40

Nakai A, Suzuki M, Tanabe M (2000) Arrest of spermatogenesis in mice expressing an active heat shock transcription factor 1. EMBO J 19: $1545-1554$

Nguyen Chi M, Chalmel F, Agius E, Vanzo N, Khabar KS, Jégou B et al (2009) Temporally regulated traffic of HuR and its associated AREcontaining mRNAs from the chromatoid body to polysomes during mouse spermatogenesis. PLoS One 4:e4900

Pelham HR (1984) Hsp70 accelerates the recovery of nucleolar morphology after heat shock. EMBO J 3:3095-3100

Piglowski W, Nowak R, Krawczyk Z, Scieglinska D (2007) The structural and functional analysis of the human HSPA2 gene promoter region. Acta Biochim Pol 54:99-106

Pulverer W, Wielscher M, Panzer-Grümayer R, Plessl T, Kriegner A, Vierlinger $\mathrm{K}$ et al (2012) The stem cell signature of $\mathrm{CHH} / \mathrm{CHG}$ methylation is not present in 271 cancer associated 5'UTR gene regions. Biochimie 94:2345-2352

Quenet D, Mark M, Govin J, van Dorsselear A, Schreiber V, Khochbin S et al (2009) Parp2 is required for the differentiation of post-meiotic germ cells: identification of a spermatid-specific complex containing Parp1, Parp2, TP2 and HSPA2. Exp Cell Res 315:2824-2834

Redgrove KA, Nixon B, Baker MA, Hetherington L, Baker G, Liu DY et al (2012) The molecular chaperone HSPA2 plays a key role in regulating the expression of sperm surface receptors that mediate sperm-egg recognition. PLoS One 7:e50851

Redgrove KA, Anderson AL, McLaughlin EA, O’Bryan MK, Aitken RJ, Nixon B (2013) Investigation of the mechanisms by which the molecular chaperone HSPA2 regulates the expression of sperm surface receptors involved in human sperm-oocyte recognition. Mol Hum Reprod 19:120-135

Reinert T, Modin C, Castano FM, Lamy P, Wojdacz TK, Hansen LL et al (2011) Comprehensive genome methylation analysis in bladder cancer: identification and validation of novel methylated genes and application of these as urinary tumor markers. Clin Cancer Res 17:5582-5592

Rezvani HR, Ali N, Serrano-Sanchez M, Dubus P, Varon C, Ged C et al (2011) Loss of epidermal hypoxia-inducible factor-1 $\alpha$ accelerates epidermal aging and affects re-epithelialization in human and mouse. J Cell Sci 124:4172-4183

Ritossa F (1962) A new puffing pattern induced by temperature shock and DNP in Drosophila. Experientia 18:571-573. doi:10.1007/ BF02172188

Rogon C, Ulbricht A, Hesse M, Alberti S, Vijayaraj P, Best D et al (2014) HSP70-binding protein HSPBP1 regulates chaperone expression at a posttranslational level and is essential for spermatogenesis. Mol Biol Cell 25:2260-2271

Rohde M, Daugaard M, Jensen MH, Helin K, Nylandsted J, Jäättelä M (2005) Members of the heat-shock protein 70 family promote cancer cell growth by distinct mechanisms. Genes Dev 19:570-582
Rosario MO, Perkins SL, O’Brien DA, Allen RL, Eddy EM (1992) Identification of the gene for the developmentally expressed $70 \mathrm{kDa}$ heat-shock protein (P70) of mouse spermatogenic cells. Dev Biol 150:1-11

Rupik W, Stawierej A, Stolarczyk I, Widłak W (2006) Promoter of the heat shock testis-specific Hsp70.2/Hst70 gene is active in nervous system during embryonic development of mice. Anat Embryol (Berl) 211:631-638

Sasaki T, Marcon E, McQuire T, Arai Y, Moens PB, Okada H (2008) Bat3 deficiency accelerates the degradation of Hsp70-2/HspA2 during spermatogenesis. J Cell Biol 182:449-458

Scieglińska D, Widłak W, Rusin M, Markkula M, Krawczyk Z (1997) Expression of the testis-specific HSP70-related gene (hst70 gene) in somatic non-testicular rat tissues revealed by RT-PCR and transgenic mice analysis. Cell Biol Int 21:813-821

Scieglinska D, Widłak W, Konopka W, Poutanen M, Rahman N, Huhtaniemi I et al (2001) Structure of the $5^{\prime}$ region of the hst70 gene transcription unit: presence of an intron and multiple transcription initiation sites. Biochem J 359:129-137

Scieglińska D, Vydra N, Krawczyk Z, Widłak W (2004) Location of promoter elements necessary and sufficient to direct testis-specific expression of the Hst70/Hsp70.2 gene. Biochem J 379:739-747

Scieglińska D, Pigłowski W, Mazurek A, Małusecka E, Zebracka J, Filipczak P et al (2008) The HspA2 protein localizes in nucleoli and centrosomes of heat shocked cancer cells. J Cell Biochem 104: 2193-2206

Scieglinska D, Piglowski W, Chekan M, Mazurek A, Krawczyk Z (2011) Differential expression of HSPA1 and HSPA2 proteins in human tissues; tissue microarray-based immunohistochemical study. Histochem Cell Biol 135:337-350

Scieglinska D, Gogler-Piglowska A, Butkiewicz D, Chekan M, Malusecka E, Harasim J et al (2014) HSPA2 chaperone protein is expressed in various human tumors and correlates with clinical features in non-small cell lung carcinoma. Anticancer Res 34: 2833-2840

Son WY, Hwang SH, Han CT, Lee JH, Kim S, Kim YC (1999) Specific expression of heat shock protein HspA2 in human male germ cells. Mol Hum Reprod 5:1122-1126

Sova P, Feng Q, Geiss G, Wood T, Strauss R, Rudolf V et al (2006) Discovery of novel methylation biomarkers in cervical carcinoma by global demethylation and microarray analysis. Cancer Epidemiol Biomarkers Prev 15:114-123

Sun F, Palmer K, Handel MA (2010) Mutation of Eif4g3, encoding a eukaryotic translation initiation factor, causes male infertility and meiotic arrest of mouse spermatocytes. Development 137:1699 1707

Terribas E, Bonache S, García-Arévalo M, Sánchez J, Franco E, Bassas L et al (2010) Changes in the expression profile of the meiosisinvolved mismatch repair genes in impaired human spermatogenesis. J Androl 31:346-357

Trinklein ND, Chen WC, Kingston RE, Myers RM (2004) Transcriptional regulation and binding of heat shock factor 1 and heat shock factor 2 to 32 human heat shock genes during thermal stress and differentiation. Cell Stress Chaperones 9:21-28

Varmuza S, Jurisicova A, Okano K, Hudson J, Boekelheide K, Shipp EB (1999) Spermiogenesis is impaired in mice bearing a targeted mutation in the protein phosphatase 1cgamma gene. Dev Biol 205:98110

Vihervaara A, Sergelius C, Vasara J, Blom MA, Elsing AN, Roos-Mattjus $P$ et al (2013) Transcriptional response to stress in the dynamic chromatin environment of cycling and mitotic cells. Proc Natl Acad Sci U S A 110:E3388-E3397

Vydra N, Malusecka E, Jarzab M, Lisowska K, Glowala-Kosinska M, Benedyk K et al (2006) Spermatocyte-specific expression of constitutively active heat shock factor 1 induces HSP70i-resistant apoptosis in male germ cells. Cell Death Differ 13:212-222 
Vydra N, Winiarski B, Rak-Raszewska A, Piglowski W, Mazurek A, Scieglinska D et al (2009) The expression pattern of the 70-kDa heat shock protein Hspa2 in mouse tissues. Histochem Cell Biol 132: 319-330

Widlak W, Vydra N, Malusecka E, Dudaladava V, Winiarski B, Scieglińska D et al (2007a) Heat shock transcription factor 1 down-regulates spermatocyte-specific $70 \mathrm{kDa}$ heat shock protein expression prior to the induction of apoptosis in mouse testes. Genes Cells 12:487-499

Widlak W, Winiarski B, Krawczyk A, Vydra N, Malusecka E, Krawczyk $\mathrm{Z}$ (2007b) Inducible $70 \mathrm{kDa}$ heat shock protein does not protect spermatogenic cells from damage induced by cryptorchidism. Int $\mathrm{J}$ Androl 30:80-87

Widłak W, Markkula M, Krawczyk Z, Huhtaniemi I (1994) Functional analysis of spermatocyte-specific hst70 gene promoter in transgenic mice. Acta Biochim Pol 41:103-105

Widłak W, Markkula M, Krawczyk Z, Kananen K, Huhtaniemi I (1995) A 252 bp upstream region of the rat spermatocyte-specific hst70 gene is sufficient to promote expression of the hst70-CAT hybrid gene in testis and brain of transgenic mice. Biochim Biophys Acta 1264:191-200

Widłak W, Benedyk K, Vydra N, Głowala M, Scieglińska D, Małusecka E et al (2003a) Expression of a constitutively active mutant of heat shock factor 1 under the control of testis-specific hst70 gene promoter in transgenic mice induces degeneration of seminiferous epithelium. Acta Biochim Pol 50:535-541

Widłak W, Scieglińska D, Vydra N, Małusecka E, Krawczyk Z (2003b) In vivo electroporation of the testis versus transgenic mice model in functional studies of spermatocyte-specific hst70 gene promoter: a comparative study. Mol Reprod Dev 65:382-388

Widłak W, Vydra N, Dudaladava V, Scieglińska D, Winiarski B, Krawczyk Z (2007) The GC-box is critical for high level expression of the testis-specific Hsp70.2/Hst70 gene. Acta Biochim Pol 54: $107-112$

Widschwendter A, Gattringer C, Ivarsson L, Fiegl H, Schneitter A, Ramoni A et al (2004) Analysis of aberrant DNA methylation and human papillomavirus DNA in cervicovaginal specimens to detect invasive cervical cancer and its precursors. Clin Cancer Res 10: 3396-3400

Wisniewski J, Kordula T, Krawczyk Z (1990) Isolation and nucleotide sequence analysis of rat testis-specific major heat shock (hsp70)related gene. Biochim Biophys Acta 1048:93-99

Wu Y, Pei Y, Qin Y (2011) Developmental expression of heat shock proteins 60, 70, 90, and A2 in rabbit testis. Cell Tissue Res 344:355-363

Ye Ch HZ, Courtney R, Zheng W, Cai Q (2012) Identification of novel breast cancer methylation biomarkers by global demethylation, cDNA microarray, and quantitative methylation analysis. Cancer Res 72(8 Supplement):4094. doi:10.1158/1538-7445.AM2012-4094

Zakeri ZF, Wolgemuth DJ (1987) Developmental-stage-specific expression of the hsp70 gene family during differentiation of the mammalian male germ line. Mol Cell Biol 7:1791-1796

Zakeri ZF, Wolgemuth DJ, Hunt CR (1988) Identification and sequence analysis of a new member of the mouse HSP70 gene family and characterization of its unique cellular and developmental pattern of expression in the male germ line. Mol Cell Biol 8:2925-2932

Zakeri ZF, Welch WJ, Wolgemuth DJ (1990) Characterization and inducibility of hsp 70 proteins in the male mouse germ line. J Cell Biol 111:1785-1792

Zhang H, Chen W, Duan CJ, Zhang CF (2013) Overexpression of HSPA2 is correlated with poor prognosis in esophageal squamous cell carcinoma. World J Surg Oncol 11:141

Zhu D, Dix DJ, Eddy EM (1997) HSP70-2 is required for CDC2 kinase activity in meiosis I of mouse spermatocytes. Development 124: 3007-3014 